\title{
「ヂフテリア菌ノ生物學的性狀卜臨牀的 所見二就テ
}

（昭和 13 年 1 月 26 日受付）

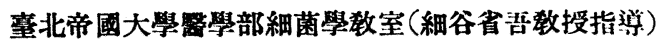

研究生關屋重德 本研究, 大要八昭和 12 年 3 月. 日本小兒科學會董灣支部第 1 间總會ニテ發表シタ
目次
V.「ヂフテリア」菌ト溶血作用

緒 言

I. 賽験材料

II. Anderson's media 上ニ於ヶル Colony 八性狀

四. Bouillon 培盖二於ヶル性狀

IV. Bouillon 培養ニ於ケル $\mathrm{pH}$ ，移動
VI.「ギフテリア」菌卜糖類分解作用

VII.「ヂフテリア」菌ト菌力站二毒素形成能

V四.「ヂフテリア」获型卜臨林的所見卜ノ關 係

總括

主要文獻

\section{緒亩}

1912 年ニ Conradi \& Tulloch ${ }^{(3)}$ ニョッテ tellurite 含ム培養基が紹介サレテカラ

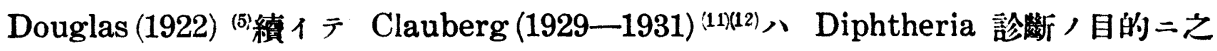
ガ應用き推稱シタ。Potassium tellurite タ最モ適當二含有スル培養基上ニ於テハ「ヂ フテリア」菌ハ他菌二比較シテ特二旺盛ナ發有テ示ストイフ事賽き應用シテ.1931 年

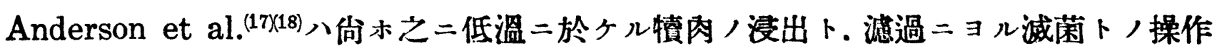
キ加へテ. 所謂 Special tellurite chocolate agar キ製作シタ。且ッ之/培地ニヨ ツテ「デフテリア」菌ノ菌型キ分類シ。生物學的性狀ト共二菌型ト臨牀的症候トタ關 連セシメテ攻究シテ. gravis, intermediate 及ビ mitis type ，3型二就テ研究き 慎表シタ。果然之ノ業績八學會ニ大ナル興味き惹起シテ. 爾來. 各地ニ於テえガ追試 或ハ復試ガ陸縝トシテ行ハレル樣ニナッタ。然シ本菌ノ分類二就テハ既 $=1924$ 年二 Hammerschmidt ${ }^{(7)}$ ) 報告ガアル。氏ガまトシテ溶血能站二 Bouillon-Culture，性 狀き基礎トシテ分類シタ 2 種, Hauptgruppe ト2種, Ủbergangsformen トチ Anderson 等, 3 型二對比シテ見ルト. Anderson， gravis ハ Hammerschmidt， 
C 型二:Mitis ハA型二一致シテ居ル樣二思ハレル。然ルニWright \& Rankin (1932)

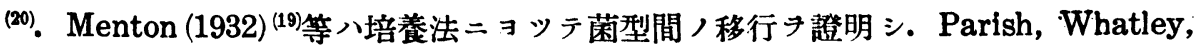
O’Brien 等 (1932) (23) 八 Park. No. 8 株(intermediate type) )毒素き以テ能動的及ビ 被働的二免疫サレタ海猽が善ク gravis type，襲摮キ防ギ mitis 及ビ gravis type ノ生菌キ夫レ夫レ游猽皮下二注射シテ反ッテ mitis type ノ方二高イ死亡率き認メタ バカリデナク. Flocculations-units ニ關シテモ同樣ノ結果デアッタ事キ報告シテ。 Anderson 等ノ說 凤反駁シタ。之二對シテ Christison(1933) ${ }^{(25)}$, Marshall(29) (1934).

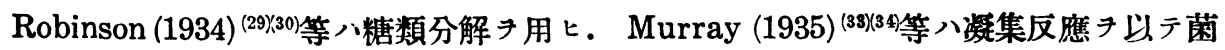
型ノ比較的安定ナルコトキ提唱シテ Anderson 說キ支持シテ居ル。1936 年. Cooper Happold, McLeod, Woodcock ${ }^{(41)}$ 等八 Anderson，流キ波ンデ. 今日マデ各地カラ

第 1 表 試 供 株

\begin{tabular}{|c|c|c|c|c|}
\hline 菌株名 & 年 部 & 男女 & 臨 轫 診 塻 & 材料探取期 \\
\hline 邱金 & 10 月 & + & 咽頭「ヂフテリア」 & 下熱後11日 \\
\hline 小田 & 14 年 & $\hat{\delta}$ & , & , 11 日 \\
\hline 大友 & 7 年 & $\hat{\delta}$ & " & " 12 日 \\
\hline 哭達 & 2 年 & 今 & 鼻「ヂフテリア」 & 9日 \\
\hline 吳林 & 9 年 & $\hat{\delta}$ & 咽顥「ヂフテリア」 & 7日 \\
\hline 过 & 7 年 & + & 鼻「ヂフテリア」 & 6日 \\
\hline 木村 & 7 年 & 우 & 咽顥「ヂフテリア」 & 3日 \\
\hline 陳而 & 3 年 & $\hat{\delta}$ & ," & 7日 \\
\hline 後藤 & 6 年 & $\hat{\delta}$ & ", & " 5 日 \\
\hline 原 & 5 年 & 우 & ", & " 4日 \\
\hline 何俤 & 2 年 & $\hat{\delta}$ & " & $" 10$ 日 \\
\hline 梅澤 & 9 年 & $\hat{\delta}$ & " & 急 性 期 \\
\hline 逢坂 & 9 年 & + & " & $"$ \\
\hline 陳英 & 2 年 & 今 & 喉頭「ヂフテリア」 & $\because$ \\
\hline 䆩田 & 9 年 & $\hat{\delta}$ & 咽頭「デフテリア」 & ", \\
\hline 永井 & 5 年 & 우 & $"$ & ." \\
\hline 洪照 & 9 年 & $\hat{\delta}$ & $"$ & ". \\
\hline 辰已 & 11 年 & $\hat{\delta}$ & $"$ & $"$ \\
\hline 滒褧 & 4 年 & $\hat{\delta}$ & $"$ & $"$ \\
\hline 岡田 & 1年 6 月 & $\hat{\delta}$ & 堠頍「ヂフテリア」 & 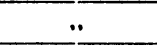 \\
\hline 洪仁 & 2 年 & $\hat{\jmath}$ & 咽頭「ヂフチリア」 & " \\
\hline 今野 & 8 年 & 우 & ", & " \\
\hline 森 & 9 年 & 今 & $"$ & $\because$ \\
\hline 吉本 & 5 年 & $\hat{s}$ & ", & 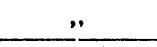 \\
\hline 寺山 & $\begin{array}{|ll|}5 & \text { 年 } \\
\end{array}$ & +9 & ", & $\because$ \\
\hline 林鶴 & 3 年 & +9 & 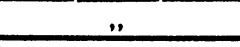 & 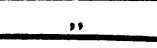 \\
\hline
\end{tabular}

報告サレタ多クノ業績き總括シ 少木同氏等， 6000 例／檢査結 果き加味シテ. 新ニ atypical type キ補充スルコトニ依ッテ そガ統一ヨ試そョウトシタ二 モ拘ラズ. Schiff \& Werbel $(1935)^{(39)}$, Mair (1936) ${ }^{(48)}$ 等ガ菌 型卜臨林的应候ト二一致點 認 メタ反面二 Perry, Whitley \& Petron(1936)(49)或ハ Henneberg \& Pels Lenden (1937) (57)等八培 養上う知見デハ 3 型キ認メルケ 乙共臨彇的所見二於テハ何等菌 型二關係スル處ガ無イト論議シ テ居ル。

要スルニ菌型卜菌力端二毒素 形成能トハ in vitro $ト$ in vivo ，實驗成績二於1テ少多少ノ矛 盾ガアル(18)(23)。余モ办最近 26 例 ノ忠者カラ分離シタ菌株二就テ 其, 生物學的性狀卜共二臨彇的 


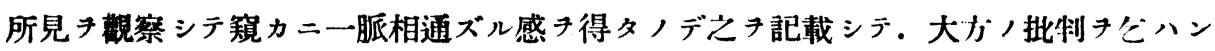
トスルもノデアル。

\section{I. 毒駼材料}

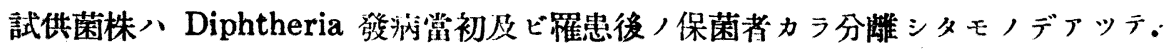

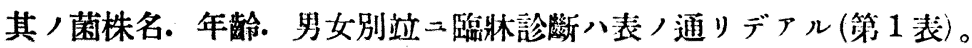

\section{Anderson's media ニ於ケル菓落ノ狀態}

今 Anderson ，所謂 special tellurite chocolate $\operatorname{agar}^{(17)}$ 人製法子略記以ルト。初 × 1.5-2.0 Pounds /槙肉子 1000 c.c. ，蒸餾水デ $48^{\circ} \mathrm{C}$. 1 時間溫浸シ. lint 7 以 テ滤過シ。次デ氷室內 $=1$ 夜放置中二滤紙滤過子行フ。其/滤液 $1000 \mathrm{ccc}=$ 二對 , Pepton(Park Davis \& $\mathrm{Co}$ ). $5 \mathrm{gr} ， \mathrm{NaCl}$ キ加へ. $45^{\circ} \mathrm{C}$ デ加溫溶解七シム几。 今. 假二之溶液 50c.c. キトリ $80^{\circ}-90^{\circ} \mathrm{C}$ デ 15 分間加熱シテ滤紙滤過シタ後 $\mathrm{N} / 1 \mathrm{Na}$ $\mathrm{OH}$ 液尹以テ $\mathrm{pH} 7.6$ 二修正シ。之二要シタ量カラ計算シテ他, 全溶液 $=\mathrm{NaOH}$ 液 キ加へル。斯クシタ後 Seitz K. キ以テ滤過シ次二 Chamberland 或ハ Seitz E. K

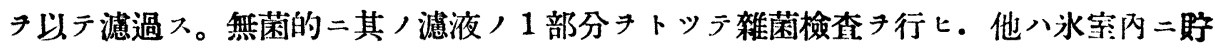
藏スル。用二臨ンデ等量ノ $5 \%$ agar 水溶液ヨ加へ.7-10\%/割合二新鮮ナ家鬼脫

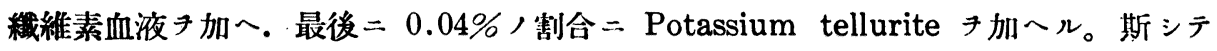
得タ溶液キ $75^{\circ} \mathrm{C}$ デ $10-15$ 分間加溫シテ「シャーレ」二流シ込に本板培養基キ作ルモ ノデァル。

以上ノ方法デ作製シタ Special tellurite chocolate agar 本板二小:記， 26 株， 「デフテリア」菌テ成ル可っ集落ガ散在スル樣二豫メ生理的食監水デ稀釋シタ後. 塗 抹シ $37^{\circ} \mathrm{C}$ デ 24 時間培養シタ後. 各菌株ノ集落ノ性狀タ「ルーペ」タ以テ精絒二觀 察シタ。此ニ Anderson 等/記載キ再錄シテ. 余ノ可檢菌株フ對照檢討シテ兄タ 1 。

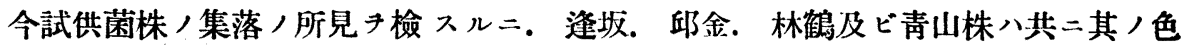

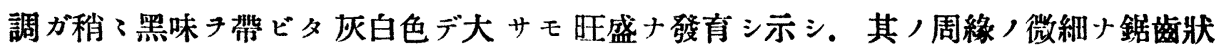
ナ點ト．中心二向ッテ多數，織條テ有スル點及ビ牛透明小周緣帶 (Semitranslucente margine) キ有シナイ點トハ最モ特異ナ性質キ示スモノデァッテ。反射光線八他； Colony 二比シテ著明ナ相違キ呈シ matt デアルノミナラズ Colony ,高サガ扁本 デアルコトハ注意スベキ性狀デアル。 
Anderson, et al. 記載，表示

\begin{tabular}{|c|c|c|c|c|c|}
\hline & Gravis & Intermediate & Mitis & $\begin{array}{l}\text { Atypical } \\
\text { Starch + }\end{array}$ & Starch - \\
\hline $\begin{array}{l}\text { Appear. } \\
\text { on spe- } \\
\text { cial } \\
\text { tellurit } \\
\text { chocol. } \\
\text { agar } 24 \\
\text { hours. }\end{array}$ & $\begin{array}{l}\text { Variant (a): Large } \\
\text { rough, grey periphery } \\
\text { black centre, with } \\
\text { radial grooving. } \\
\text { Consistency of cold } \\
\text { margarine. } \\
\text { Variant (b): smaller } \\
\text { smoother than above } \\
\text { with consistency } \\
\text { nearer to butter. }\end{array}$ & $\begin{array}{l}\text { Fine flat, with } \\
\text { fine central } \\
\text { papilla, grey } \\
\text { margin and } \\
\text { black centre. } \\
\text { Consistency } \\
\text { intermediate } \\
\text { between gravis } \\
\text { and mitis. }\end{array}$ & $\begin{array}{l}\text { Medium raised } \\
\text { convex, with black } \\
\text { centre and grey } \\
\text { semitranslucent } \\
\text { periphery. } \\
\text { Consistency of warm } \\
\text { butter. Black is the } \\
\text { predominant shade } \\
\text { in these cultures } \\
\text { (grey in gravis } \\
\text { cultures) }\end{array}$ & $\begin{array}{l}\text { Approxi- } \\
\text { mates to } \\
\text { mitis. }\end{array}$ & $\begin{array}{l}\text { Gravis } \\
\text { or appro- } \\
\text { ximating } \\
\text { to gravis }\end{array}$ \\
\hline $\begin{array}{l}\text { Growth } \\
\text { in } \\
\text { broth. }\end{array}$ & $\begin{array}{l}\text { (a) Marked pelicle } \\
\text { and coarse granular } \\
\text { deposit, broth } \\
\text { remaining relatively } \\
\text { clear. } \\
\text { (b) Pellicle less } \\
\text { marked, coarse } \\
\text { granular deposit and } \\
\text { general turbidity. }\end{array}$ & $\begin{array}{l}\text { Fine granular } \\
\text { turbidity tending } \\
\text { to sediment } \\
\text { within } 48 \mathrm{~h} \text {. } \\
\text { never profuse. }\end{array}$ & $\begin{array}{l}\text { Diffuse turbidity, } \\
\text { usually profuse and } \\
\text { often with late soft } \\
\text { Pellicle. }\end{array}$ & $\begin{array}{l}\text { As mitis } \\
\text { with } \\
\text { some } \\
\text { granular } \\
\text { deposit. }\end{array}$ & $\begin{array}{l}\text { As } \\
\text { gravis. }\end{array}$ \\
\hline $\begin{array}{l}\text { Reaction } \\
\text { in } \\
\text { broth. }\end{array}$ & $\begin{array}{l}\text { Initial } \\
\text { acidity followed by } \\
\text { rapid reversion to } \\
\text { alkaline reaction. }\end{array}$ & $\begin{array}{l}\text { Very little } \\
\text { change. }\end{array}$ & $\begin{array}{l}\text { Initial acidity } \\
\text { with slow } \\
\text { reversion, }\end{array}$ & $\begin{array}{l}\text { Not } \\
\text { observed }\end{array}$ & $\begin{array}{l}\text { Not } \\
\text { observed }\end{array}$ \\
\hline $\begin{array}{l}\text { Haemo- } \\
\text { lytic } \\
\text { activity. }\end{array}$ & Some strains. & Negative. & Usual. & $?$ & $?$ \\
\hline $\begin{array}{l}\text { Ferment. } \\
\text { of poly- } \\
\text { sacchari- } \\
\text { de. }\end{array}$ & + & - & - & + & - \\
\hline $\begin{array}{l}\text { Animal } \\
\text { pathoge- } \\
\text { nicity. }\end{array}$ & Constant. & $\begin{array}{l}+ \text { except in } \\
\text { a few strains. }\end{array}$ & Usual. & Slight. & Irregular \\
\hline
\end{tabular}

之等，菌株二最モ良ク類似シテ。洪仁。木村. 吉本. 森. 今野及ビ过株ノ6株ハ

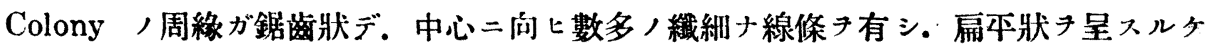
レドモ.Colony ガ小サク周線二著明ナ牛透明ナ周緣带キ有スルコト二特異ナ相違點 キ示シテ居ル。色澤モ稍 、 matt デアルガ集落ノ中心が乳頭狀二隆起シテ然カモ異 黑ノ色調星シテ扂ル。

以上: 10 株ノ菌株キ除ケバ. 残りノ 16 株ハ皆一樣二集落ノ周緣ハ全ク圓形デアッ

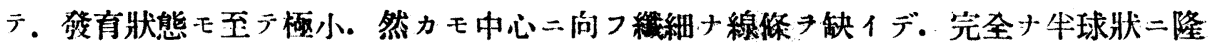

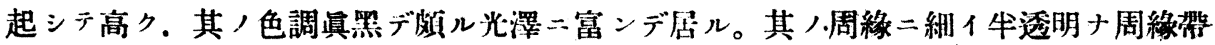
フ有スルコトノ ハ八前, 6 株二近似シチッル。 
以上ノ 3 群ノ集落ノ性狀ノ內最前ノ 4 株ト最後ノ16株トハ共ニ「ヂフテリア」菌ナ ガラ. 全ク異ツタ形狀キ示シテ到底同種菌ノ集落トハ思ハレナイ程隔ツタ外䚋キ呈 シテ居ル。今之等, 3 群ノ集落ノ形狀 $尹$ Anderson ノ記載二比隼シテ考察スルト。 最前ノ 4 株 gravis type 二. 最後つ 16 株ハ mitis type 二. 中間二述べタ 6 株 八Intermediate type 二一致スル事が肯定サレル。故二斯ル Anderson's special tellurite chocolate agar 上ニ於ケル集落ノ形狀キ基礎トシテ假りニ 3 群ノ菌型二分 ツテ以下其ノ各菌株ノ生物學的ノ諸症性狀き探索シテ胃ヨり。

\section{Bouillon 培宾二於ケル性狀}

Bouillon ハ Martin-bouillon $(\mathrm{pH} 7.0)$ キ使用シ $37^{\circ} \mathrm{C} 24-48$ 時間培養き觀察入ル コト・シタ。

先ジ第 1 = gravis 型郎チ逢坂. 邱金。林鶴及ビ青山株キ觀ル二.24 時間後デ培養

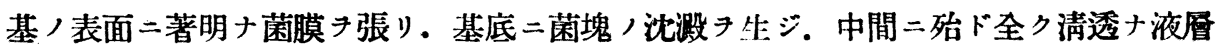
ア遺ス。菌膜八比較的腪固ナ感がアル。

第 2 二 Intermediate 型ノ6株二於テハ殆ド凡テ菌膜き有スルモ或ル菌株ハ gravis 型ノ如ク簕固ナモノアリ又或者八非常二菲薄デ一定シナイ。例へバ木村. 今野. 辻株 デハ菌膜甚ダ厚ク固ク且ツ。基底二菌塊ノ沈没生ジ中間二清透ナ液層き遺シテ。 gravis 型菌ト比べテ殆ド相違ガナイ。然シ洪仁. 吉本及ビ森株八菌膜菲薄デアッテ基

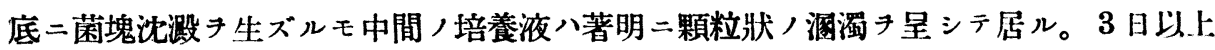
培養フ經過スルトキハ斯ル顆粒八漱次基底二沈行シテ中間ノ液ハ透明トナル。

第 $3=$ mitis 型二屬入ベキ 16 株二就テ見ルト多種多樣, 像キ示シテ居ル。郎于翠 固ナル菌膜き作ツテ培養液ノ清透ナモノ二陳英. 原. 吳達株アリ. 菲薄ナ菌膜き生ジ

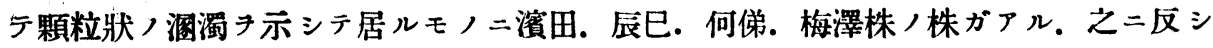

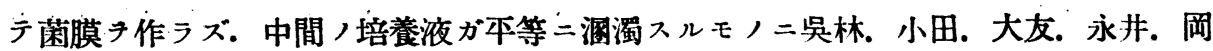
田. 鄭發。後藤。陳怔及ビ洪照ノ9株ガアル。然カモ其洞濁タルヤ粗大ナルモノ。微 細ナルモノガアッテ自ラ區々ノ狀テ旺シテ扂ル。

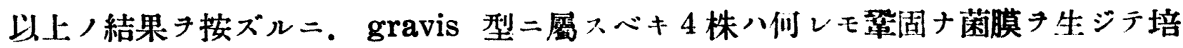

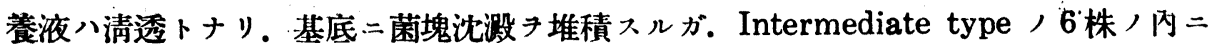

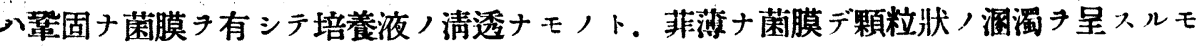
ノトアッテ其數相牛シテ居ル。更二 mitis type 16 株二就テハ多種多樣ナ所見フ呈シ テ. 或ルモノ八 gravis 型菌ノ如ク厚固ナ闲膜卜清透ナ培養液き衣シ或ルモノ八菲游 
第 2 表 Bouillon 培善二於ヶル性狀

\begin{tabular}{|c|c|c|c|c|c|c|c|}
\hline \multirow{2}{*}{$\begin{array}{l}\text { 菌 } \\
\text { 型 }\end{array}$} & \multirow{2}{*}{ 株名 } & \multicolumn{3}{|c|}{24 時間培盖 } & \multicolumn{3}{|c|}{47 时間培養 } \\
\hline & & |菌膜 & 犬熊 & 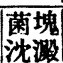 & 膜 & 润滛 & 葍 \\
\hline \multirow{4}{*}{$\begin{array}{l}\text { 勈 } \\
\frac{n}{3} \\
0 \\
0\end{array}$} & 逢坂 & $\mathrm{HH}$ & 清 & H & m & 透 & H \\
\hline & 邱金 & H & 粗大顆䊉. & H & ++ & 透 & H \\
\hline & 林鶴 & H & 清 & $\mathrm{HH}$ & H & 透 & H \\
\hline & 青山 & H & 清 & $\mathrm{HH}$ & H & 透 & \# \\
\hline \multirow{6}{*}{ 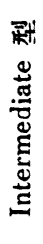 } & 木村 & $\mathrm{HH}$ & 清 & $\mathrm{HH}$ & \# & 透 & 世 \\
\hline & 洪仁 & + & 細 顆 粒。 & H & $+t$ & 粗大顆粒 & 世 \\
\hline & 㠿本 & tt & 粗大顆籹. & $H$ & H & 粗大顆粒. & W \\
\hline & 森 & $H$ & 細顆 粒 & $H$ & $t+$ & 粗大顆䊉。 & H \\
\hline & 今野 & H & 透 & $\mathrm{HH}$ & H & 透 & H \\
\hline & 过 & $\mathrm{HH}$ & 清 & $\mathrm{HH}$ & H & 清 & W \\
\hline \multirow{16}{*}{ 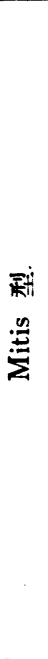 } & 洪照 & - & 本等窑 & $t+$ & - & 細 顆 粒 & H \\
\hline & 辰已 & + & 細微顆粒 & + & + & 粗大顆䉼。 & H \\
\hline & 濱田 & + & 細微顆柆。 & $H$ & + & 細微顆䊉。 & $t+$ \\
\hline & 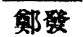 & + & 透 & $t+$ & + & 透 & $H$ \\
\hline & 洞田 & - & 本等 濁 & + & - & 平等 濁 & + \\
\hline & 永井 & - & 細顆 粒 & $H$ & + & 粗大顆䉼 & $H$ \\
\hline & 梅澤 & - & 本等 濁 & $H$ & - & 䪶籹 & $H$ \\
\hline & 陳英 & $t+$ & 粗大顆粒 & H & $+t$ & 粗大顆粒 & H \\
\hline & 吴林 & - & 本等濁 & + & - & 本等 濁 & + \\
\hline & 何俤 & $\mathrm{HH}$ & 透 & $H$ & H & 透 & $H$ \\
\hline & 大友 & - & 本等 润 & - & - & 本等 濁 & + \\
\hline & 吳達 & - & 本等 濁 & + & $+H$ & 清 & H \\
\hline & 小田 & - & 平等 䁌 & + & - & 本等濁 & + \\
\hline & 陳祉 & + & 細顆 粒。 & + & + & 粗大顆粒 & $H$ \\
\hline & 後藤 & + & 細微顆䉼 & + & + & 細微顆粒 & + \\
\hline & 原 & + & 清 & $H$ & - & 細微顆粒 & + \\
\hline
\end{tabular}

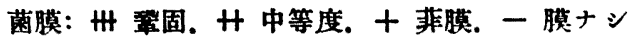
沈激 $\mathrm{HH}+\mathrm{H}$ 量的二。
ナ菌膜キ作ツテ顆粒狀溷濁き來 シ㕛或ルモノ八菌膜キ生ゼズ. 本等溷濁フ星シテ區々トシテ分 類シ難イ。然ルニ mitis 型二 屬ス可キ菌株ハ菌膜き作ラズ本 等溷濁ノモノガ多ク約 $56 \%$ 示 シテ居ル(第 2 表)。

\section{Anderson ${ }^{(17)(18)}$ 始 Cooper,}

Happold (41) 等. Marshall (29), Christison ${ }^{(25)}$ 等ノ報告 二徵シテ gravis 型菌ハ菌膜が著明デ培 養液ノ清透デアル點八。余ノ成 績ト善ク一致シテ居ルガ mitis 型ニアツテハ彼等八菌膜き作ラ ズ、本等浭濁デアルト云フノニ 反シテ余ノ害驗二於テハ菌膜， 硬軟及ビ培養液ノ清濁等區々タ ルモノデアッテ其ノ性狀ガ一定 シナイ。蓋シ Bouillon 培養二 アッテハ gravis 型カラ mitis 型二至ル楷梯二於テ菌自體, 發 育ノ盛衰二從七多種多樣ナ現象 キ現ハスモノト思考サレル。

加之 Bouillon 培養ニ於テ菌膜キ作ルト作ラナイトハ培食二際シ其ノ手技二依ツテモ 左右七ラル、コトガアル。例へバ intermediate 或ハ mitis type 二於ケル菲薄ナ菌

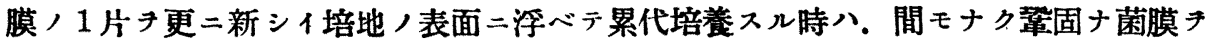

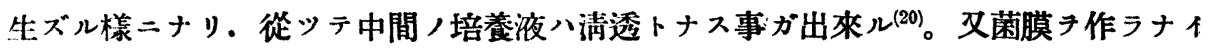
mitis 型デアッテモ斯樣ナ培養手技ニヨッテ培養キ累ネル場合ハ遂二菌膜キ生ゼシメ ルコトガ出來ル。之二反シテ菌膜キ作ル可キ菌株ニ於テモ菌キ培養液梁ク基底二投入

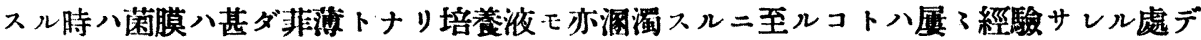

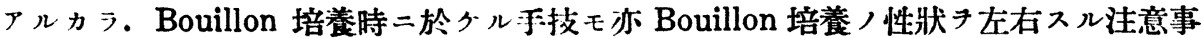


項デアル。

\section{Bouillon 培養ニ於ヶル水素「イオン灌度ノ移動}

「ヂフテリア」菌テ液體培地內二培養スル場合， $\mathrm{pH}$ ，移動ニ就テハ Diphtheriatoxin 產生, 研究二重要ナ問題デァルノミナラズ. 本菌ノ菌型ニョッラ變化ヌ示ス篇 二多數ノ先進諸家ノ業績がアル。Anderson et al. ${ }^{(17)(18)}$ 圤 = Cooper et al. ${ }^{(11)}$ 八 mitis type 八起始酸性反鷹ガ alkali 性二轉向スルノニ緩慢デァッテ 4-5 日ォ要シ. intermediate 型菌ニアッテハ極メテ僅少二起ル二過ギナイ・之二反シテ gravis 型菌二於 テハ甚ダ活潑デアッテ 2 日ノ後二轉向スルト云ヒ. Robinson ${ }^{(30) 八 ~ i n t e r m e d i a t e ~ t y p e ~}$ ニアッテハ遂二 alkali 轉向キ現ハサナイト云ッテ居ル。メ Wright \& Christison ${ }^{(21)}$ 八第 II 型葙 (intermediate 二相當) ハ 12 日以上キ要スルト報䇠シテ扂ル。

第 3 表 Martin-bouillon $(\mathrm{pH} \mathrm{7.0)}$ 二於ヶル $\mathrm{pH}$ ，移動

\begin{tabular}{|c|c|c|c|c|c|c|c|c|c|}
\hline 菌型 & 菌株名 & 18時間 & 特間 & 2 日 & 3 日 & 4 日 & 5 日 & 7 日 & 10 日 \\
\hline \multirow{4}{*}{ 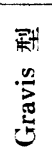 } & 逢 坂 & 7.0 & 6.6 & 6.2 & 56 & 6.6 & 6.6 & $\cdots 0$ & 8.0 \\
\hline & 邱 金 & 7.0 & 6.8 & 6.8 & 7.0 & 7.6 & 7.2 & 7.8 & 7.8 \\
\hline & 林 鶴 & 7.0 & 7.0 & 7.0 & 7.4 & 7.8 & 7.8 & 8.4 & 8.6 \\
\hline & 青 山 & 6.6 & 6.6 & 6.8 & 6.8 & 7.0 & 7.2 & 8.0 & 8.6 \\
\hline \multirow{6}{*}{ 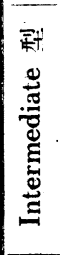 } & 木 村 & 7.2 & 6.8 & 7.2 & 5.6 & 5.7 & 7.7 & 8.8 & 9.0 \\
\hline & 洪 仁 & 7.0 & 7.0 & 7.4 & 8.4 & 8.4 & 8.4 & 8.4 & 9.2 \\
\hline & 吉 本 & 7.0 & 7.0 & 7.2 & 7.2 & 7.6 & 8.4 & 8.8 & 9.2 \\
\hline & 森 & 7.0 & 6.8 & 7.0 & 7.0 & 7.2 & 7.2 & 7.6 & 8.4 \\
\hline & 今 野 & 7.0 & 7.0 & 7.0 & 7.2 & 7.6 & 8.4 & 9.4 & 9.4 \\
\hline & 过 & 7.0 & 7.0 & 7.4 & 7.8 & 8.4 & 8.4 & 8.4 & 9.0 \\
\hline \multirow{16}{*}{ 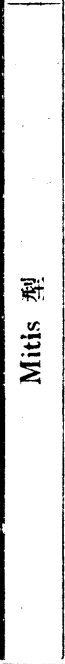 } & 洪 照 & 0 & 7.0 & 7.0 & 7.0 & 7.0 & 7.4 & 7.8 & 8.0 \\
\hline & 辰 巳 & 0 & 0 & 7.0 & 7.2 & 7.4 & 7.8 & 8.6 & 3.0 \\
\hline & 演 田 & 0 & 0 & 7.0 & 7.0 & 7.4 & 7.6 & 3.4 & 8.8 \\
\hline & 鄭 發 & 0 & 0 & 7.0 & 7.0 & 7.0 & 7.6 & 7.8 & 7.8 \\
\hline & 阊 田 & 0 & 7.0 & 7.2 & 7.8 & 8.4 & 8.4 & 8.4 & 3.4 \\
\hline & 永 并 & 0 & 6.8 & 7.2 & 7.4 & 7.8 & 8.8 & 8.8 & 9.4 \\
\hline & 梅 澤 & .0 & 7.0 & 7.0 & 7.8 & 8.4 & 8.4 & 8.4 & 8.4 \\
\hline & 陳英 & 7.0 & 7.0 & 7.2 & 7.0 & 7.0 & 7.2 & 7.8 & 7.8 \\
\hline & 㓳 林 & 7.0 & 7.0 & 7.0 & 7.4 & 7.4 & 7.8 & 8.4 & 9.2 \\
\hline & 何 俤 & .0 & 7.0 & 7.2 & 7.8 & 8.4 & 8.8 & 9.4 & 9.0 \\
\hline & 大 友 & .0 & 7.0 & 7.0 & 7.2 & 2.6 & 7.6 & 8.4 & 8.4 \\
\hline & 题 達 & 7.0 & 7.0 & 7.2 & 7.2 & 7.6 & 7.8 & 8.4 & 9.2 \\
\hline & 小 田 & 7.0 & 7.0 & 7.2 & 7.4 & 7.8 & 8.4 & 8.4 & 8.4 \\
\hline & 陳 祉 & 7.0 & 7.0 & 7.2 & 7.0 & 7.0 & 7.2 & 7.8 & 7.8 \\
\hline & 後 藤 & 7.0 & 7.0 & 7.0 & 7.0 & 7.0 & 7.2 & 7.8 & 7.8 \\
\hline & 原 & 7.0 & 7.0 & 7.0 & 7.0 & 7.0 & 7.2 & 7.8 & 8.4 \\
\hline
\end{tabular}


余八本菌接種，Martin-bouillon $7 \mathrm{pH} 7.0$ 二修整シテ $37^{\circ} \mathrm{C}$ 二培盖シ. 18 時間

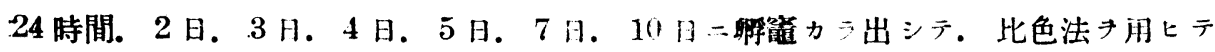
pH 7測定シタ(第3 表)。

1.記表二就1テ兄儿柡二 gravis type 逢坂株ハ7日二王ツテ濑》 alkali二轉问シ

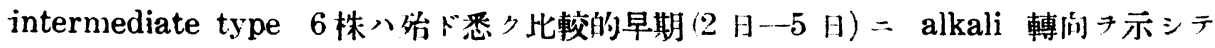
Robinson, Wright 及ビ Christison 等, 成緽ト甚ダ異ツタ結果尹招來シタ。然ル二

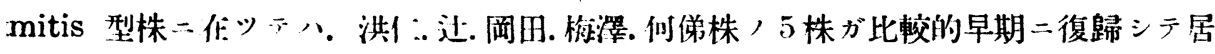
ル外. 他，11株八檄不 Anderson, Cooper, Robinson, Wright 其, 他 Christison ノ成縜トー致シタ所見デアル。要スルニ「ヂフテリア菌，Bouillon 培養二於らル $\mathrm{pH}$ ，移動扯調八其，菌株二據ツテ多種多樣デ. 菌型卜，關係二就イテハ判然トシタ

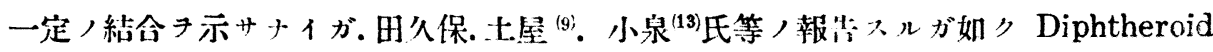
其,他類似藏卜，壏別二重要デアラウ。

\section{V. ヂフテリア 菌ノ溶血作用}

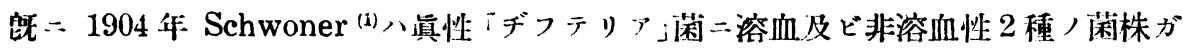

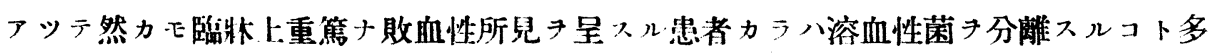

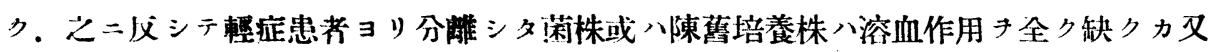

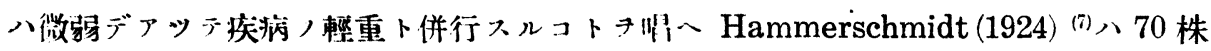
，Diphtheria 株中 53 株， 二溶血性タ認メテ。本菌タ溶血型及ビ非溶血型ノ $2 \%$ , Haupt-gruppe ト2 種, Ủbergangsformen トキ區別シタ。小泉氏 (1929) ${ }^{(13) 八 人 ~}$

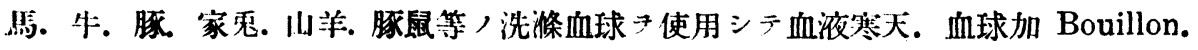

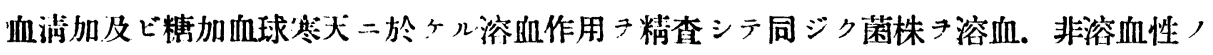

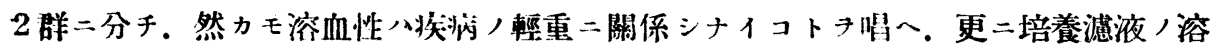

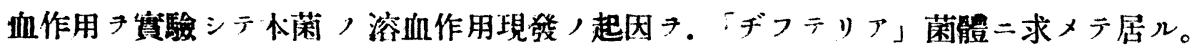
Anderson et al. 八 mitis type ガ常二溶血性デ gravis type 八非溶血性デアルト

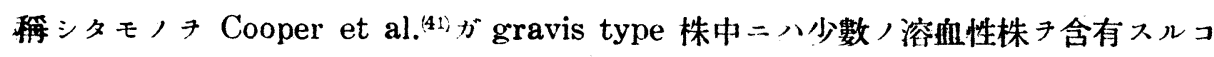
ト近二 intermediate type ガ非溶血性デアルコトキ修正シタ。沿木 Robinson \& Marshal (1934. a ${ }^{(29)}$, Robinson (1934. b.) ${ }^{(30)}$. Christison (1933) ${ }^{(25)}$, Menton (1932),(19) Wright \& Rankin (1932)(20) 等》各菌型二色々，Variant，モノガアッラ長期間. Bouillon 培食テ繼程スル時ハ溶血ヨリ非溶血二變異スルコトチ報告シテ居ルガ本邦 二代ツテモ古ク小泉氏 (昭和 4 年) ガ異セザルコトタ. 近ク井.上. (昭和 10 年) ${ }^{(40)}$ 及ビ西 


\begin{tabular}{|c|c|c|c|c|c|c|}
\hline \multirow{16}{*}{ 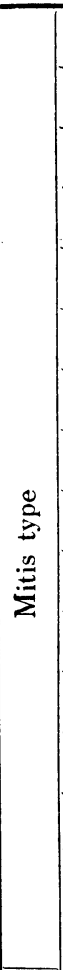 } & 果 & + & 1 & + & ". & 1 \\
\hline & 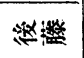 & + & 1 & + & $\stackrel{5}{0}$ & 1 \\
\hline & 繁崖 & + & + & + & $\stackrel{+}{0}$ & 1 \\
\hline & 표 & + & 1 & + & $\stackrel{\vartheta}{0}$ & -キ \\
\hline & 账㙋 & + & 1 & + & $\stackrel{\vartheta}{0}$ & 一丰へ‡ \\
\hline & $K K$ & + & 1 & + & $\stackrel{\vartheta}{0}$ & 1 \\
\hline & E贯 & 1 & 1 & + & $\stackrel{?}{0}$ & 1 \\
\hline & 啾关 & + & 1 & + & $\dot{+}$ & 1 \\
\hline & 邆场 & + & 1 & + & $\stackrel{\vartheta}{0}$ & 1 \\
\hline & 慗琏 & + & 1 & + & 'ं & - \\
\hline & 栄米 & 1 & 1 & + & $\begin{array}{l}\vartheta \\
\bullet\end{array}$ & 1 \\
\hline & 匡王 & + & 1 & + & $\begin{array}{l}0 \\
0\end{array}$ & 一夆 \\
\hline & 制 & + & 1 & + & $0^{\circ}$ & $m \neq$ \\
\hline & 琎正 & + & 1 & + & $\dot{0}$ & N丰的‡ \\
\hline & 峂工 & + & 1 & + & $\stackrel{+}{0}$ & のますキ \\
\hline & 苏㫛: & + & 1 & + & $\stackrel{\sim}{0}$ & ๙ま \\
\hline \multirow{6}{*}{ 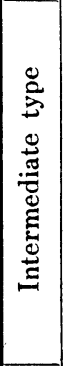 } & iो & 1 & 1 & + & $\stackrel{7}{\circ}$ & 1 \\
\hline & <资 & 1 & 1 & 1 & मं & 1 \\
\hline & 类 & 1 & 1 & 1 & 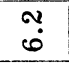 & 1 \\
\hline & 扣米 & 1 & 1 & + & $0^{\circ}$ & 1 \\
\hline & 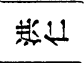 & + & 1 & + & $\stackrel{?}{0}$ & ๙ま \\
\hline & 长 & 1 & 1 & 1 & சं & 1 \\
\hline \multirow{4}{*}{ 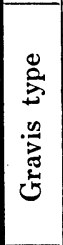 } & AE & + & + & + & $\stackrel{\circ}{\circ}$ & 1 \\
\hline & 英恶 & 1 & 1 & 1 & $0^{+}$ & 1 \\
\hline & 鱼低 & 1 & 1. & 1 & $\stackrel{?}{0}$ & 1 \\
\hline & 絒资 & 1 & 1 & 1 & $\begin{array}{l}\vartheta \\
0\end{array}$ & 1 \\
\hline 础 & $\begin{array}{c}\text { F } \\
\text { 棞 } \\
\text { 热 }\end{array}$ & 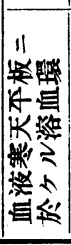 & 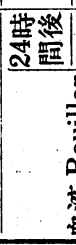 & 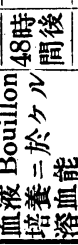 & 되롤 & 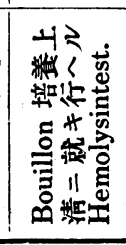 \\
\hline
\end{tabular}

山氏 (昭和 12 年) ${ }^{(69)}$ ガ綡異スルコト キ報告シタ。不最近 Kemkes \& Steigler (1937) ${ }^{(62)}$ 八木菌／浴血能力

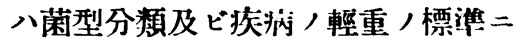
ナラナイコトキキ噍シテ府ル。

余モ亦所持 26 株二就イデ次 3 途二㨜ツテ菌型卜溶血能力ト, 關係 キ檢討シタ。先ジ川羊，脫悢維素血 液 10\%含有寒犬，本板 $1:=$ Colony ガ散在スル樣二堿菌食監水二テ稀䅴： サレタ菌株キ塗抹シテ $37^{\circ} \mathrm{C} 24$ 時間 及ビ 48 時間培善シタ後. Colony， 周浚二生ズル溶血環，有無キ检㮅シ タ。

次二八家鬼,脫絟維䒺血液子數滴 投ジタ普通 Bouillon 中二菻キ移植 シ $37^{\circ} \mathrm{C}=2$ 日間培誉シテ湖溶血 層ノ有無二就イテ觀然シタ。最啳二 揸通 Bouillon 中 $-37^{\circ} \mathrm{C} 2-3$ 日培養 シタモノ、上清液キ静カ ニ Pipette キ以テ咒ヒ取リ。減菌食留水キ以テ 倍數稀䆁シタモノキ1.0c.c. 宛小試驗 管三取り之二家鬼，1\%洗條血球液 チ等量宛加へテ $37^{\circ} \mathrm{C}$, wasserbad 中デ加溫シナガラ 1 時間後. 3 時間 後及ピ玟朝ノ 3 回，溶血 /有無二就 イテ觀祭シタ。此二之等，賽驗成績 フ一括シテ表示入ルト次ノ通リデナ ル(第 4 表)。

血液寒天本板上，溶血環子 24 時 閒及ビ48時閒啳二检スル二甚分䫤著 
ノモノアリ。僅少ノモノアリ，シテ其，程度八區々トシラ居ルガ Colony 周渗タ變色シ

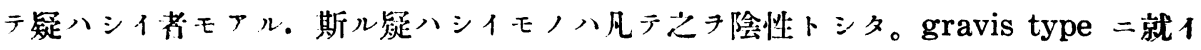
テ罗ルト青川株が溶血性デ他３株ハ除性ォ呈シタ。intermediate type デ八洪仁株 ガ陽性ブ殘儿 5 株八㓌性キ示入。更二 mitis type 八菌株尹检スルト 2 例(何俤. 永井 株) 7除キ 14 株悉り溶血性デアツタ。血液 Bouillon 培養, 場合ハ gravis type 八全 ク血液寒天不板I: 所胃卜‥致シテ居ルノニ反シ。 intermediate type 二於テハ 24 時間デ全株悉”㓌性デアッタモノガ 48 時閒後二至ツテ 3 株郎于洪仁. 吉本. 过株が溶 血性子挸ハシ。殘ル 3 株ハ俍然トシテ非溶血性デフル。mitis type デハ血液寒天， 場合卜略: 同一) 結果デ 24 時間後カラ 48 時間二至ル間二悉ク溶血性キ呈シタ。又.

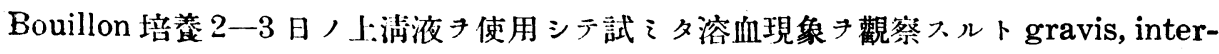
mediate type 一屬入可キ菌株ハ洪仁株テ除外シテ 1-3 時間後デハ凡テ，例二於テ 溶血作用キ現ハサナイが㯟朝二至レバ gravis，林鶴. 青山株. intermediate ノ洪 二. 今野株が僅二溶血性キ示スノミデアル。 mitis type キ觀レバ血液寒天本板泣二 Blut-bouillon，晹合卜比較シテ著明二相違シテ大部分，菌株ガ㓌性デアル。然ル二 柆朝トナレバ何俤. 永井株ノ2株き除イテ凡テ陽性タ示シテ居ッタ。

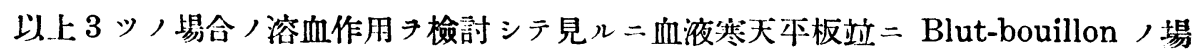
合ハ gravis 及ビ mitis type 二於テ Anderson et al. Cooper et al. ノ記載卜善 ク一致スルコトが解ル。然ルニ intermediate type デハ Cooper et al. Robinson \& Marshall. Christison \& Wright 等ノ所說ノ樣二決定的二一律デナカッタ。師于血液 寒天本板デ 1 例. blood-bouillon デ 3 例ノ異端老キ出シタコトハKemkes \& Steigler ノ所說キ裹苦シタ所胃デァル。

\section{VI.「ヂフテリア」茵ト糖類分解作用}

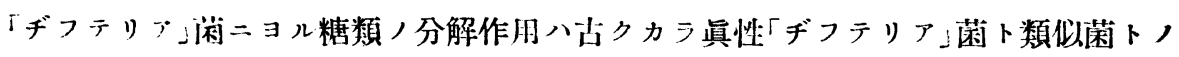

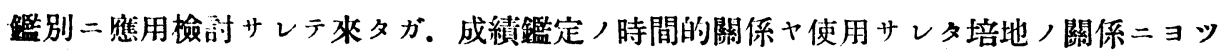

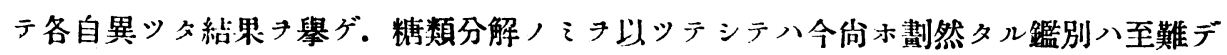
アルトハ云へ。大1二見ル可キ淮境キ示シテ居ル。即チ Graham-smith (1907) (?). Neisser (1913) (4) Paul Engering (1922) (6) 田人保及ビ土屋 (1928) ${ }^{(9)}$. Jensen \& Falk

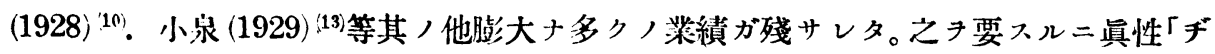

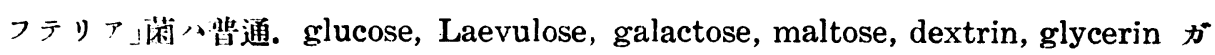
分解サレ Lactose, saccharose, inulin, rabinose, mannit, salicine 等き分解シナ1 
第 5 裴 Hiss 培地二於ヶル糖類分解

\begin{tabular}{|c|c|c|c|c|c|c|c|c|c|c|}
\hline 型 & $\begin{array}{l}\text { 畐 } \\
\text { 株 } \\
\text { 名 }\end{array}$ & 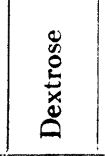 & 总 & 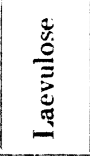 & $\frac{\mathscr{n}}{\stackrel{n}{n}}$ & : & & 怘 & $\frac{\bar{v}}{\bar{v}}$ & : \\
\hline \multirow{4}{*}{ 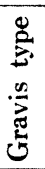 } & 逢 坆 & +5.2 & +6.8 & +5.4 & +6.2 & -7.0 & -6.8 & +6.2 & +5.4 & $=-7.0$ \\
\hline & 邸 金 & +5.2 & +5.6 & +5.4 & +6.4 & -6.8 & -6.6 & +5.8 & +5.6 & -7.2 \\
\hline & 林 鶴 & +5.6 & +5.8 & +5.6 & +6.4 & -6.8 & -6.8 & +6.2 & -7.0 & $-\pi .0$ \\
\hline & 毒 山 & +5.4 & +6.0 & +5.6 & +6.2 & -7.2 & -6.8 & +6.6 & $\overline{+6.0}$ & -7.0 \\
\hline \multirow{6}{*}{ 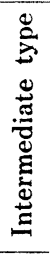 } & 木 村 & +5.2 & +5.0 & +5.4 & +6.0 & -7.4 & +5.6 & +5.2 & -7.4 & -7.6 \\
\hline & 港 仁 & +5.2 & +6.0 & +5.4 & +6.8 & -7.0 & -6.6 & +5.4 & -7.6 & -7.4 \\
\hline & 悲 本 & +5.4 & +5.8 & +5.4 & +6.0 & -7.2 & -6.8 & +5.6 & -7.0 & -7.2 \\
\hline & 森 & +5.2 & +6.0 & +5.6 & +6.0 & -7.6 & -6.8 & +5.6 & -7.2 & -7.0 \\
\hline & 今 野 & +5.0 & +5.6 & +5.4 & +5.6 & -7.0 & +5.6 & +5.2 & -7.4 & -7.4 \\
\hline & 过 & +5.2 & +5.6 & +5.4 & +6.6 & -7.0 & -7.4 & +5.2 & -7.4 & -7.0 \\
\hline \multirow{16}{*}{ 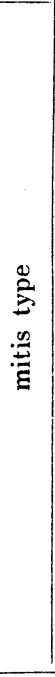 } & 洪 照 & +5.4 & +5.6 & +5.4 & + & -7.6 & -6.6 & +5.6 & -7.4 & -7.8 \\
\hline & 辰 已 & +5.2 & -6.2 & +5.8 & +5.4 & -7.6 & -6.6 & +5.6 & -7.4 & -7.0 \\
\hline & 濱 田 & +5.0 & +5.6 & +5.8 & +5.6 & -7.2 & -6.6 & +5.4 & -7.6 & -7.4 \\
\hline & 鄭 發 & +5.4 & +6.6 & +5.4 & +6.2 & -7.0 & -6.6 & +5.6 & -7.4 & -7.0 \\
\hline & 阔田 & +5.2 & -6.6 & +5.4 & +5.6 & -7.0 & -6.6 & $\overline{+6.2}$ & -7.6 & -7.4 \\
\hline & 永 井 & +5.2 & -6.0 & +5.6 & +6.6 & -7.0 & -6.6 & -6.2 & -7.6 & -7.4 \\
\hline & 梅 濢 & +5.4 & +6.2 & +5.4 & +6.6 & -7.2 & -6.6 & -6.8 & -7.6 & -7.2 \\
\hline & 陳 英 & +5.4 & -6.2 & +5.4 & $\overline{+6.6}$ & -7.0 & -6.6 & -6.8 & -7.0 & -7.2 \\
\hline & 吳 林 & +5.0 & +6.4 & +5.6 & +5.8 & -7.0 & +5.8 & +5.6 & $\overline{-7.0}$ & -7.8 \\
\hline & 何 俤 & +5.0 & +5.6 & +5.4 & +5.6 & +5.6 & +5.6 & +5.6 & -7.2 & +5.6 \\
\hline & 大发 & +5.0 & +5.6 & +5.6 & +6.2 & -7.0 & -6.2 & +6.0 & -7.4 & -7.0 \\
\hline & 哭 達 & +5.2 & +6.4 & +5.4 & +5.6 & -7.2 & -6.6 & $\overline{+5.6}$ & -7.4 & -7.4 \\
\hline & 小 田 & +5.2 & +6.0 & +5.4 & +5.6 & -7.2 & -6.8 & +5.6 & -7.6 & -7.4 \\
\hline & 陳 部 & +5.4 & +5.8 & +5.4 & +6.4 & -7.0 & +5.8 & +5.6 & -7.4 & -7.2 \\
\hline & 後 藤 & +5.0 & +6.0 & +5.4 & +5.6 & -7.0 & $\overline{+5.6}$ & +5.2 & -7.4 & -7.4 \\
\hline & 原 & +5.0 & +5.4 & +5.4 & $\overline{+6.8}$ & -7.0 & +6.8 & $\overline{+5.2}$ & $\overline{-7.2}$ & -7.2 \\
\hline & 照 & 7.8 & 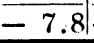 & 7 & -7.8 & -7.8 & -7 . & $\pi$ & -7.8 & -7 \\
\hline
\end{tabular}

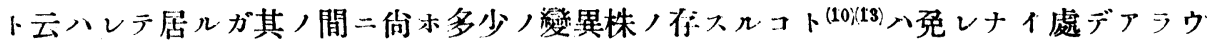
然ルニAnderson (1931. a) ${ }^{(11)}$ ，蒋績ガ發玟サレルヤ本菌，糖類分解能八更二進ンデ gravis, mitis, intermediate type，茵型間，區別二應用セラレル樣ニナリ。余 其ノ意我テ深クシ. 殊二Starch，分解能否ガ其ノ重點キ焦火二至ッタ。或几菌株二 據ツテ「ヂフテリア」菌ガ測粉. glycogen キ分解大ルコトハ既二前述諸氏ニヨツテ

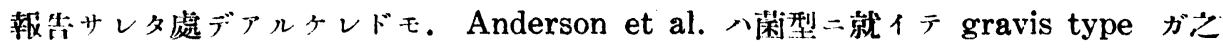
テ分解シ. mitis, intermeoliate type ハきキ分解シナイト唱へタ。更二又. Ewing

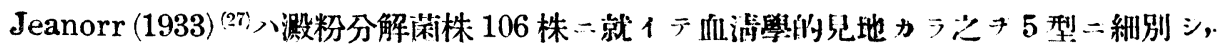


其ノA．B及ビ D型八完全二Leed's worker 記載，gravis type二一致スルガ C型八

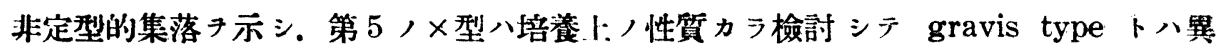
ツタ菌株デァリナガラ測粉フ分解ハルト唲へタ。余モ Anderson et al. 二倣ツテ患 者カラ分踓シタ 26 株二就イテ Hiss's serum-water $ォ$ 使用シテ糖類分解試驗 䞑之夕。

Hiss's serum-water 八1.0\% 隇菌糖類溶液 (Lithmus 添加)二健康馬, 血清

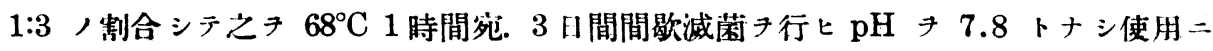
供シタ。接種サレタ Hiss 培地キ $37^{\circ} \mathrm{C}=3$ 日間培荃シテ $\mathrm{pH}$ 测定ニョッテ酸形成キ 檢榃入ルト同時二其ノ赤變如何キ觀祭シタノデアル。勿諭糖キ加へナイ serum-water

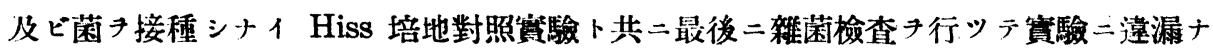
キコトキ期シタコトハ言チ俟タナイ(第 5 表)。

Glucose. Galactose, Laevulose, Maltose 八全株が之き分解シ。 Dextrin 八 mitis type， 3 株き除イテ最多数株ガ分解シタ。Lactose, mannit 八唯 mitis type，何 俤株 1 例子例外トシテ悉クシテ分解シ小イ。Saccharose 二於テハ gravis type 4 株 八凡テ陰性. intermediate type 6 株中僅二2株が之キ分解シテ残几 4 株ハ分解シナ

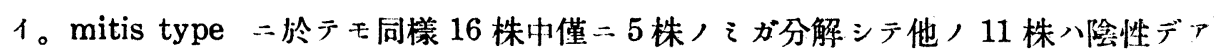
ツタ。Starch二就イテ昌ルト gravis type 4 株中デ 3 株がえき分解シ. 林鶴株 1 例 ノ々八分解タ示サズ. 酸ノ發生モ起サナカッタ。之二對シテ Intermediate type 站 二 mitis type / 菌怢八黑クそキ分解以ル能力ガナカツタ。gravis type デ starch

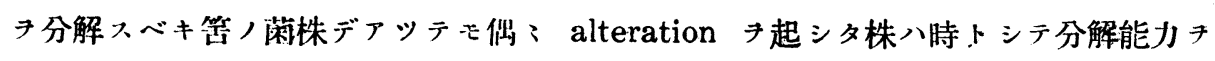
夫フ事貨二就イテ. Anderson, Robinson, 或八 Wright \& Christison ${ }^{(21)}$ 等モえキ認 メテ居ルカラ. 余ノ寡驗二於テ gravis type 林鶴株 1 例が陰性デアッテモ敢テ奇異 トスルニ足ラナ1。其ノ後.「ヂフデリア闲ノ斯ル菌型が安定的ナモノデアルカ否か キ檢討シタ Christison(1933) $)^{(25)}$, Robinson (1934) ${ }^{(30)}$, Murray (1935) ${ }^{(34)}$ 等，實驗結果

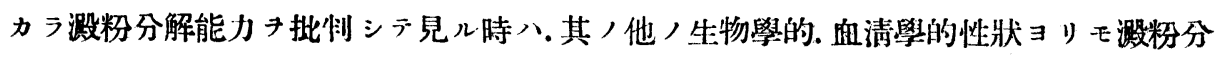
解能力八最モ安定们ナ性質デアッテ备菌型，Variant ニ於テサへ. mitis, intermed iate type カラ出筑シタ變異株、Starch 7 分解シ得ナイ。從ッテ本菌, 菌型分類二 最て重要デアルト稱シテ居ル。

\section{VII.「チフテリア」菌ノ菌型ト菌カ竝ニ毒素形咸能}

仰々 Corynebacterium 二於イテ鿓性「ヂフテリア」菌タ其ノ類似菌カラ分制ス几標 


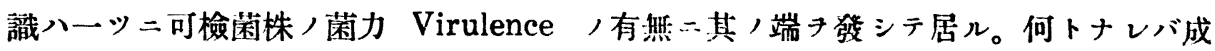
書デ見ル樣ニ B. diphtheriae ガ游猽二對シテ有凊デアルノニ反シテ B. xerosis. B.

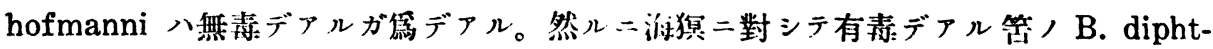
heriae モ場合ニヨリテ非常二有毒的二作成久几裹面二又全ク無表:的二等生スルコト ノアル事實八今日確證サレタ處デアル。緒けデ述べタ樣二無毒性ノ「ヂフテリア」菌が

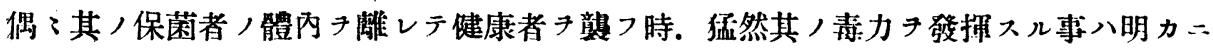
斯ル事實キ證查スルモノデアラウ。Brückner (1934) (28) 八彼ガ患考端二保菌者カラ採 集シタ 62 株ノ「ヂフテリア」菌二就イテ生物化舉的檢查ト動物二對スル表性ト二準據

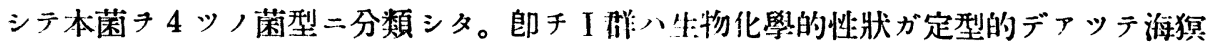
二對シ有毒ナモノ．II 群ハ定型的デアルガ源猽二對シテ無毒ナモノ．群八非定型的 ナガラ(Dextrose, Laevulose, Maltose ノミナラズ Saccharose キモ分解スル)。濰 猽二有毒ナモノＩVI群ハ非定型的デアルト同時二淮猽ニモ無毒ナルモノ(郎チ類似菌)

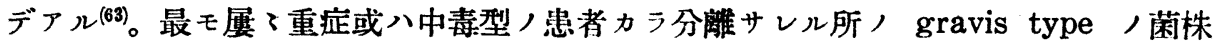
ガ其, Virulence 二於テ. 最モ屡了輕症患者カラ得ラレル mitis type，菌株ヨリ モ常二高度ナ菌力チ現ハストハ限ラナイ。と二就イテ Anderson et al. ${ }^{(18)}$ 自身及ビ Parish et al $^{(23)}$, Robinson \& marshall ${ }^{(29)}$ モ斯ク報告シタシ. 余モ亦 gravis, intermediate 及ビ mitis type，菌株き生理的食監水浮游液トナシ. 淮猽睪丸實質內二注射

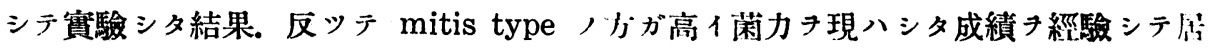

第 6 表 幼若海䐎二對スル M.L.D.

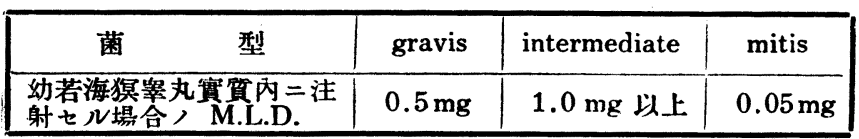

以上入各菌量 $=$ 就キ海㺍 2 䫒宛 $\exists$ 使用シテ得タ成績デアル $\iota^{(67)}$ (第 6 表)。

Gundel (1936) ${ }^{(43)}$ 八 gravis, mitis intermediate type 13 型 菌株, Bouillon 24-48 時間培養液ヲ 0.2c.c. 宛. 海猽皮下 $=$ 注射シテ得タ成績ニヨ ツテ gravis 型ガ最モ强イ菌力及ビ Invasionsvermägen キ有シ。 mitis 型ガ最モ微 弱ナ菌力デナルノミナラズ其， Invasionsvermägen モ亦最少デアッタコトタ報雀

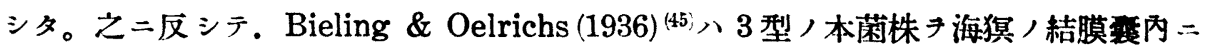

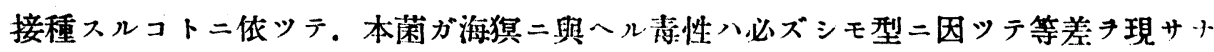
イコトキ賽驗シタ。

以上ノ樣二菌型卜 Virulence 二就イテノ關係二在ツテ八確固タル相连ハ無イガ嗮 ツテ菌型ト毒素産生能力ト, 關係八如何。

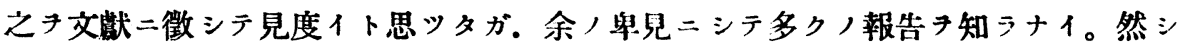




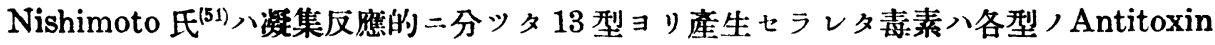
卜同樣二等差ナク中和サレルコトチ報告シ。1932 年 Parish, Whatley \& O'Brien ${ }^{(29)}$ 等八動物二對スル 3 型菌, Virulence キ檢スルト同時二試驗管內二於テ 3 型菌ノ毒 素形成能力丹賽驗シテ. mitis 株ニ於テハ 16-20 L. f. units アッタノニ對シ。 gravis 株ニアッテハ僅ニ 0-6 L. f. units キ産生シタニ過ギナイ. 且ツ斯ル成績入

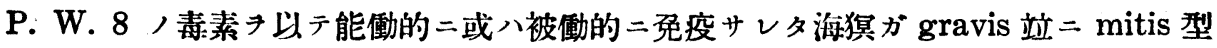

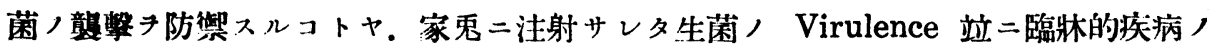
軖重二關スル菌型，研究結果が善ク一致シテ. gravis 必シモ grave ナラズ. mitis ガ必シモ mite ナラザルコトキ報告シタ、1933 年 Anderson, Cooper, Happold \& McLeod ${ }^{(10)}$ 等モ O’Brién カラ分变サレタ本表素き海猽及ビ家兔二皮下注射シテ.同樣

第 7 表 各菌型八菌株ヨリ獲タ毒素 液 ，幼若海猽二對スル M.L.D.

\begin{tabular}{|c|c|c|c|c|}
\hline 落型 & 菌株名 & $\begin{array}{l}\text { end } \\
\text { pH }\end{array}$ & M.L.D. & 剖見 \\
\hline \multirow{4}{*}{ 总 } & 逢坂 & 8.2 & $1 / 100^{c . c}$. & 定型的 \\
\hline & 邱金 & 7.8 & $1 / 10$, & ", \\
\hline & 林鶴 & 9.6 & $1 / 100$, & " \\
\hline & 青山 & 8.8 & $1 / 100$, & " \\
\hline \multirow{6}{*}{ 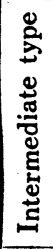 } & 木村 & 8.8 & $1 / 10 "$ & $"$ \\
\hline & 洪仁 & 8.0 & $1 / 10$, & , \\
\hline & 皆本 & 8.6 & $1 / 10$, & $"$ \\
\hline & 森 & 8.6 & $1 / 50 \quad$. & 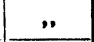 \\
\hline & 今野 & 8.8 & $1 / 100 "$ & $"$ \\
\hline & 迲 & 8.0 & $1 / 10 \quad$, & 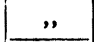 \\
\hline \multirow{16}{*}{ 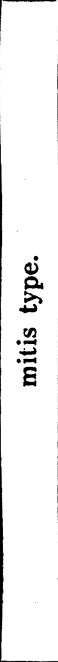 } & 洪照 & 8.2 & $1 / 10 \quad$, & " \\
\hline & 辰已 & 8.6 & $1 / 10 "$ & ", \\
\hline & 渰田 & 8.6 & $1 / 50 \quad$, & $"$ \\
\hline & 矤警 & 8.2 & $1 / 10$, & $"$ \\
\hline & 岡田 & 7.8 & $1 / 10 "$ & " \\
\hline & 永井 & 9.2 & $1 / 10$, & " \\
\hline & 梅㵋 & 8.2 & $1 / 50 \quad$, & " \\
\hline & 陳英 & 8.4 & $1 / 50 \ldots$ & $"$ \\
\hline & 吴林 & 8.6 & $1 / 10 "$, & " \\
\hline & 何俤 & 8.6 & $1 / 10$, & " \\
\hline & 大友 & 8.2 & $1 / 10 \quad$, & $"$ \\
\hline & 哭達 & 7.8 & $1 / 10$, & " \\
\hline & 小田 & 8.4 & $1 / 10$ & $"$ \\
\hline & 陳和 & 8.2 & $1 / 50 \quad$, & $"$ \\
\hline & 後藤 & 9.2 & $1 / 50 \quad 1$ & $"$ \\
\hline & 原 & 9.2 & $1 / 100 \ldots$ & $\|$ \\
\hline
\end{tabular}

二 Mitis-toxin ノ方が掌ロ gravis-toxin $コ$ ロ 優秀ナ致死力キ現ハシタ第ニ人間ノ場合卜實驗動 物ノ場合卜ノ間二大キナ矛盾キ肯定シテ居ル。

余ガ急性症狀ノ患者站二罹患後下熱シテ 4 日一 12 日ヨ經過シタ恢復期ノ患者カラ分離七ル 26 株 二就イテ其ノ表溸形成能キ賽驗シタ結果キ記載シ ヨウ。

培地 $0.1 \%$ 葡萄糖加 Martin-bouillon (pH7.8) チ使用シタ。初メ新二 Löffler 培地二接種サレタ 「ヂフテリア」菌キ 10c.c.， Martin-bouillon $=2$ 日間隔デ 3 代. 培養シタモノキ 30 c.c. ノ Martinbouillon ノ表圍二移植シテ $37^{\circ} \mathrm{C}$. 9 日間培餋シ タ後. 雜菌檢查後直 チ $=$ Tolnol キ以テ殺菌. 2 日 間室溫. 暗所二放㯰シテ $\mathrm{pH}$ 人測定後. 滤紙滤過 シテ毒素液テ得タ。鳢重 $250 \mathrm{gr}$. 內外, 幼若海猽 キ選ビ. Bouillon キ以テ原液。10．50．100，200 倍二稀程シタ青素液ノ1.0 c.c 其ノ大腿皮下二注 射シテ動物ノ生死如何 7 日間觀察シテ海猽二對 スル m. l. d. チ測定シタ。斃死シタ海猽八直于 二解剖二附シ定型的中毒死デアルカ否カキ检證シ タ事ハ目豆キ俟タナイ(第 7 表)。 
第 7 表二據ツテ察久ルニ gravis type ニアツテハ邱金株ノミが $1 / 10$ c.c. デ殘り 3 株

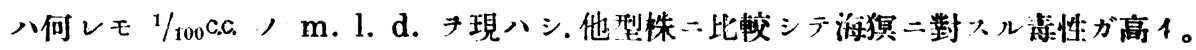
intermediate type デハ 6 株中 4 株が1/1,c.c. 2 株が $1 / ; 0$ ト 1/106c.c. ， m. l. d. デ

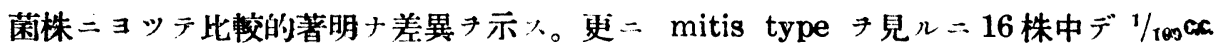

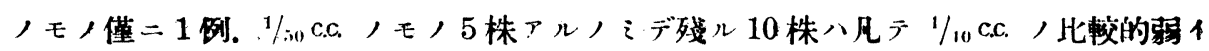
毒素形成能

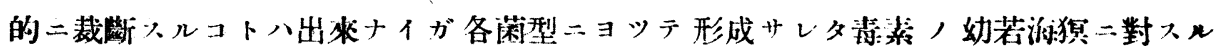

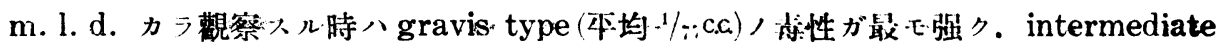

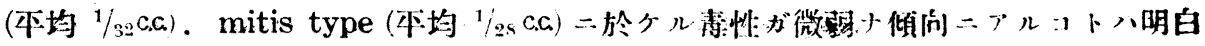
デアル。

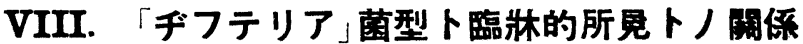

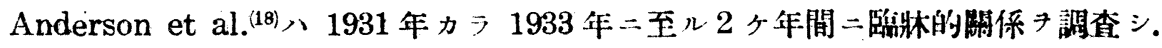

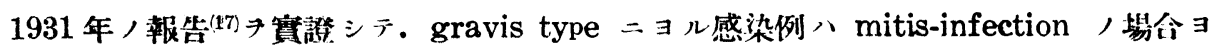
リモ血清療法ノ效果が掦がラナイ。郎チ gravis-infectionノグ重篤デフルト報告

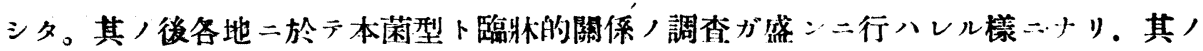
數賽二枚舉二㟫ガナイ。

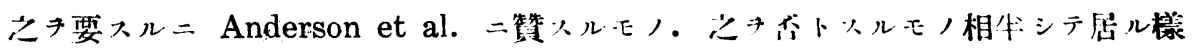

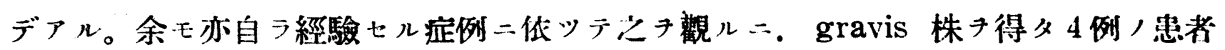

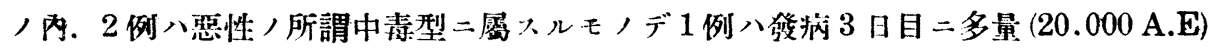

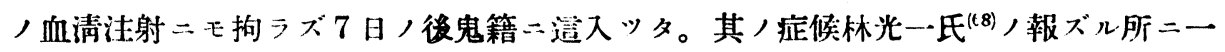
致シテ心臟衰弱. 腎炎. 頸部淋巴腺腫脹. Faetor ex Orae 等著明デアッタ。他，1

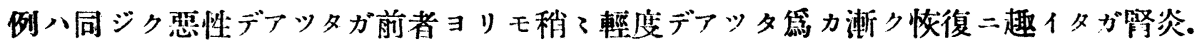

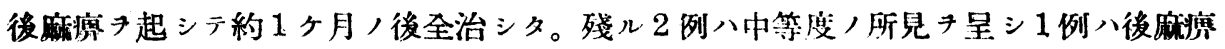

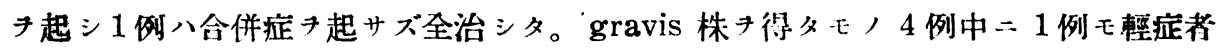
キ見ナカツタコトハ注目二傮入ル所デアラウ。

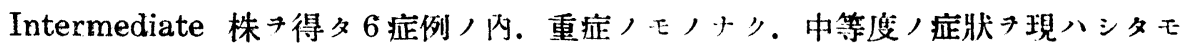

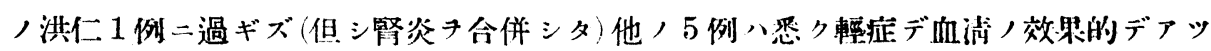
タコトハ恰モ mitis type，樣ブアル。

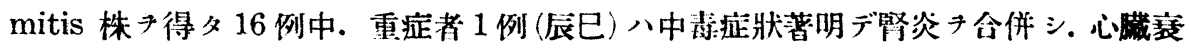

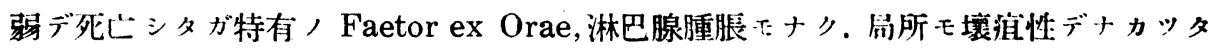




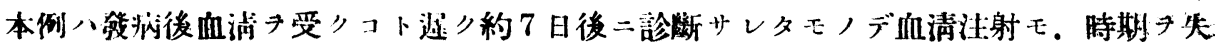

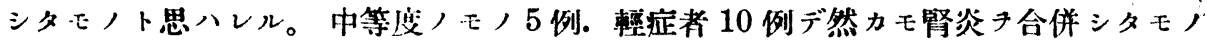

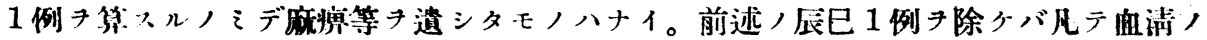

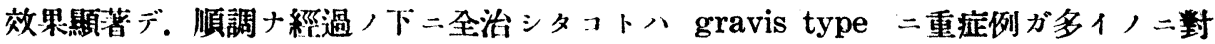

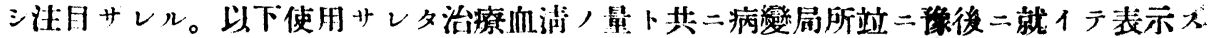
儿(第 8 表)。

第 8 輩菌型卜臨林的關係

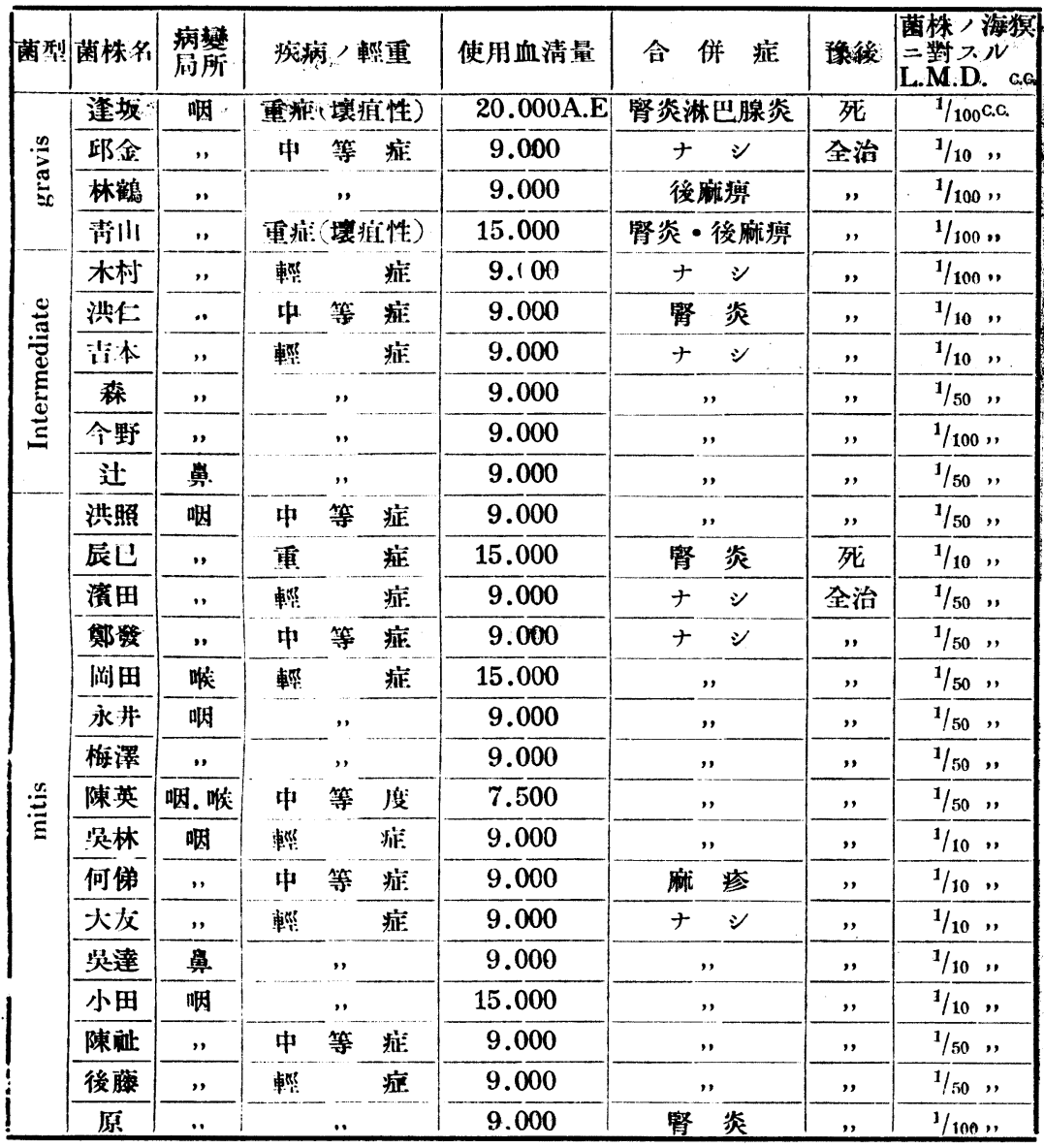

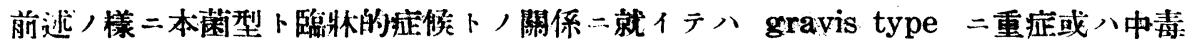

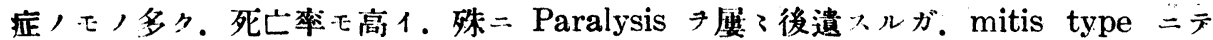

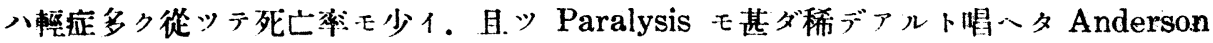

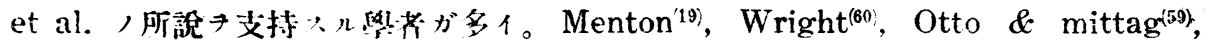


Henneberg \& Pels Lenden ${ }^{(57)}$, Gundel ${ }^{(44)}$, Hettche ${ }^{(36): 37 ; 38)}$, Tannabill ${ }^{(47)}$, Schiff \& Werber ${ }^{(39)}$, 等。然ル $=$ Perry, Whitley \& Petran ${ }^{(49)}$, Corter ${ }^{(42)}$, Becker $^{(58)}$, Hilgers

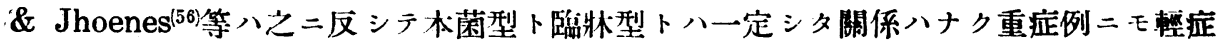
例二モ等シク各型がアッテ數字的二一括サル可キ偭问認メナイト反䮎シテ居儿。又 Leed (Anderson et al.) 及ビ Leipzig (Becker) 地ガデ八 gravis type ガ非常二多1 ノ二反シテ Glasgow (Corter). Capetown(Wright. J.) 等デハ少イト云フ樣二地少的 二甚ダシイ相違ガアルノそナラズメ. 各流行二於テモ菌型ノ變動がアルコトハ各地ノ文

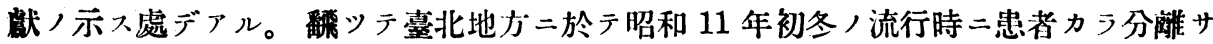
レタ吾が 26 株二就イテ其ノ成績キ觀ルニ gravis-infection $=15.4 \%$. intermediateinfection $23 \%$ 及ビ mitis-infection ガ $61.5 \%$ リリ歐洲各地ノ報告二比シ gravisinfection ガ著明ニ少ク. mitis-infection ガ多イコトキ表ハシテ居ル。然ルニ gravis type 二重症者ガ多ク. mitis 及ビ intermediate type 二輕症例ガ多カッタコト茫二 gravis type 二於テ Paralysis キ經驗シタ事ニ就テハ Anderson et al. 其ノ他多ク ノ實驗者ノ成績ト完全ナ一致キ示シタ。

第 9 表 可檢菌株, 菌型卜臨林的輕重，Percentage.

\begin{tabular}{|c|c|c|c|c|c|}
\hline 臨林的關係 & gravis & \multicolumn{2}{|c|}{ Intermediate } & mitis & total \% \\
\hline 症 & 2 例 $50 \%$ & & 0 & 例 & 3 例 $11.5 \%$ \\
\hline 中 等 症 & 2 例 $50 \%$ & 1 例 & $16.6 \%$ & 5 例 $31.2 \%$ & 8 例 $30.8 \%$ \\
\hline 輕 & 0 & 5 例 & $81.7 \%$ & 10 例 $62.5 \%$ & 15例 $57.6 \%$ \\
\hline 合 㐼 症 & 3 例 $75 \%$ & 1 例 & $16.6 \%$ & $25 \%$ & $27 \% 0$ \\
\hline 死 & 1 例 & & 0 & 1 例 & $7.7 \%$ \\
\hline $\begin{array}{l}\text { 總菌株數二對 } \\
ル \text { Percentage. }\end{array}$ & $15.4 \%$ & & $23 \%$ & $61.5 \%$ & \\
\hline
\end{tabular}

\section{總 括}

1. 患者站二罹患後ノ保菌者カラ分雖シタ 26 株ノ「デフテリア」菌ヲ Anderson's media 二培養シ 23-48 時間二觀察シ. Colony 八性狀二據ツテ 3 型 gravis, intermediate 及ビ mitis type 二分類スルコトガ出來タ。可检 26 株/内 gravis type 4 株 intermediate type 6 株. mitis type 16 株デアッタ。

2. Martin-bauillon $(\mathrm{pH} 7.0)$ 中二 $37^{\circ} \mathrm{C} 24$ 乃至 48 時間培養入ル時八闲株ニョリ

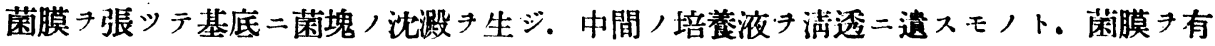

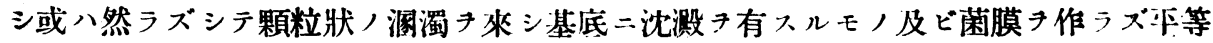

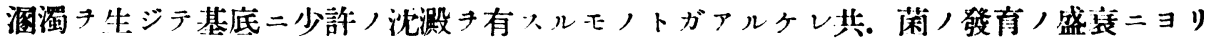


其間二區々ナル移行性ガアッテ 3 型，區別キ唯立セシメ難イ。然ルニ獨リ gravis: type 八秒了特有ナ倾向き示人。

3. Bouillon 培養二於ケル $\mathrm{pH}$ ，移動ハ菌株ニヨッテ移動步調が區々タル樣き呈 シ. 菌型ニョッテ統一サレタ性狀タ認メラレナカッタ。

4.「デフテリア」菌ノ溶血作用八血液寒天本板上二於ケル Calony 周圍ノ溶血環 有無. blood-bouillon 二培養シテ溶血性,有無站二Bouillon 培養；上清二就イテ Hemolysintest タ检查シタガ mitis type 最モ良ク溶血シ gravis, intermediate type ニ在ツテハ 1.2 ，例外キ含ンデ一般二溶血シナイ。Bouillon 培飬ノ上清ニ就イテ溶 血作用八最モ惡ク，血液寒天本板上ノ試驗法ガ最モ適當デアル。

5.「ヂフテリア」茵ショル粧類分解試驗デ八 Hiss's serumwater キ使用シ。 3 日 間觀然ノ結果凡テノ「デフテリア」菌株いGlucose, Galactose, Laevulose, Maltose 及ビ Dextrin キ分解スルガ Lactose, Mannit ハ之キ分解シナイ。 Saccharose 二就 イテハ gravis type 八分解シナイ. intermediate 及ビ mitis type ノ少數株ノミが 分解シテ大多數ノ菌株ハ分解シナカッタ。Starch 二就イテハ gravis type，モノ殆 ドルテシキ分解スルノニ反シ intermediate 及ビ mitis type ノモノ八悉ク分解シナ 1。即于多數先進學者, 成䋶卜全ク一致シタ結果デアル。

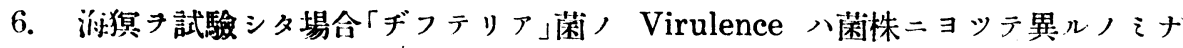
ラズ. 菊型二就イテ見テモ高低ノ莽ハナイ。

然ルニ Martin-bouillon二接種シテ9 日間培養シタ場合ノ毒素形成能二就イテハ 概シテ gravis type ガ强イ毒素キ形成シ mitis type ガ最モ多數例二於テ弱イ青素タ 形成スル傾向二在ツタ。郎チ幼若淮猽二皮下注射シタ場合， m. l. d. 八本均 gravis

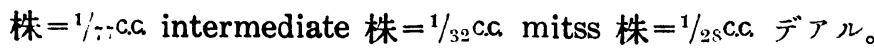

7. 菌型卜臨林的所見，䡬重二關シテハ gravis type 八主トシテ重症或八中等症 例カラ獲ラレヌ合併症キ發ス几事ガ多イ。Paralysis キ後遺スルコトガアル。

intermediate 及ビ mitis type ハ圭トシテ中等症拉二輕症患者カラ獲ラレ合併症ヨ 併發スルコトモ少イ。特ニ Paralysis ヨ後遗シタ例ガ無カッタ。

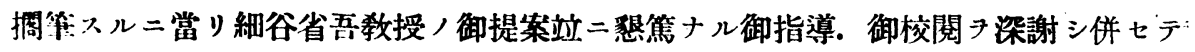
教突，先彗永井．田中. 寺田兄及ビ學友藏田兄，援助二感謝／意丹表スル。

\section{主要文苚}

1) Schwoner, J., (1904), Zbl. f. Bakt. I. Orig. 35, 608.

2) Graham-Smith, G. J., (1907), Jour. of Hyg. VI, 286. 
3) Conradi, H, \& Tulloch, P., (1912), Münch. med. Wochs. 59, 1652.

4) Neisser, (1913), Zbl. f. Bakt. I. Ref. 57, Beiheft. 1.

5) Douglas, S. R., (1922), Brit. jour. experm. Path. 3, 263.

6) Paul. Engering, (1922), Zbl. f. Bakt. I. Orig. 89, 120.

7) Hammerschmidt, J., (1924), Zbl. f. Bakt. I. Orig. 93, 443.

8) Hammerschmidt, J., (1935), Klin. Wschr. 14, 964-966.

9）田久保，土屋，(1928)，細菌學雜誌. 386 號，30頁. (㫿利 3 仅).

10) Jensen, L. B. \& Falk, 1. S., (1928), Jour. of. bact. 15, 367.

11) Clauberg, K. W., (1929), Zbl. f. Bakt. I. Orig. 114, 539.

12) Clauberg, K. W., (1931), Zbl. f. Bakt. I. Orig. 120, 324.

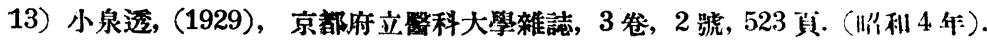

14) Dimitrijevic-Speth, V, \& Javanovic, L.. (1931), Zbl. f. Bakt. I. Orig. 121, 64.

15) Dimitrijevic-Speth, V, \& Javanovic. L., (1931), Zbl. f. Bakt. I. Orig. 121, 432.

16) Dimitrijevic-Speth, V, \& Arsenijevic, K., (1937), Zbl. f. Bakt. I. Orig. 139, 282.

17) Anderson, J. S., Happold, F. C., McLeod, J. W., and Thomson, J. G., (1931), Jour. of path. and bact. XXXIV; 667.

18) Anderson, J. S., Cooper, K. E., Hoppold, F. C., and MaI.eod, J. W., (1933), Jour. of path. and bact. XXXVI; 169.

19) Menton, J., (1932), Jour. of path. and bact. XXV; 651.

20) Wright, H. A, \& Rankin, A. L. K., (1932), Lancet, II. 884.

21) Wright, H. A. \& Christison, M. H. in Collaboration With A. L. K., Pearson, R. C. M. and Cuthbert, J. A., (1935), Jour. of path. and bact. XLI; 447.

22) Broom, J. C. and Brown, H. C., (1932), Brst. jour. of exper. Path. XIII; 337.

23) Parish, H. J., Elsie, E., Whatlay \& O'Brien, R. A., (1932), Jour. of path. and bact. XXXV 625.

24) 杉江四郎, (1932)，日本傳染病學雜誌，6 卷，5號，467 頁. (明利 7 午).

25) Christison, M. H., (1933), Jour. of path. and bact. XXXVII: 243.

26) Christison, M. H.. Wright. H. A, \& Shearer, B. J., (1936), Jour. of path. and bact. XLII; 345.

27) Ewing, Jean orr, (1933), Jour. of path. and bact. XXXVII; 345.

28) Brückner, M., (1934), Zeitschr. f. Hyp. 116, 361.

29) Robinson, D. T. \& Marshall, F. N., (1934), Jour. of path. and bact. XXXVIII; $\approx 3$.

30) Robinson, D. T., (1934), Jour. of path. and bact. XXXIX; 551.

31) Robinson, D. T. \& Peeney, A. L. P., (1936), Jour. of path. and bact. XXXXIII; 403.

32) Murray, J. F., (1935), Jour. of path. and bact. XLI; 97.

33) Murray, J. F., (1935), Jour. of path. andbact. XLI: 439.

34) Murray, J. F., (1935), Brit. jour. of exper. Path. XVI; 384.

35) Murray, J. F., (1935), Brit. jour. of exper. Path. XVI; 532.

36) Hettche. H. O., (1935), Zbl. f. Bakt. I. Orig. 134, 321. 
37) Hettche, H. O., (1935), Zbl. f. Bakt. I. Orig. 134, 433.

38) Hettche, H. O., (1935), Zeitschr. f. Hyg. 117, 33.

39) Schiff, F. und 'Werber, M., (1935), Dtsch. med. Wschr. 61, 259-262.

40) 井上清萿，(1935)，兒科雜誌，427號，1827 頁，(㗊和 10 年).

41) Cooper, K. E., Happold, F. C., McLeod, J. W. \& H. E. de C. Woodcock, (1936), Proceed. of Royal Society of Med. XXIX; 1029,

42) Corter, H. S., (1936), Jour. of Hyg. 36, 147.

43) Gundel, M. \& Erzin, N., (1936), Zbl. f. Bakt. I. Orig. 136, 24.

44) Gundel, M., (1936), Klin. Wschr. 15, 1871-1875.

45) Bieling, R. und Oelrichs, L., (1936), Zbl. f. Bakt. I. Orig. 137, 226.

46) Freuner, (1936), Zbl. f. Bakt. I. Orig. 137, 112.

47) Tannabill, R. W., (1936), Jour. of Hyg. 36, 140.

48) Mair, W., (1936), Juur. of path. and bact. XXXXII; 635,

49) Perry, C. A., Whitley, O. R. and Petran, E., (1936), Amer. jour. of Hyg. XXIII; 580.

50) Pesch, K. L., (1936), Klin. Wschr. 15, 1202-1203.

51) Nishimoto, G., (1936), Zeitschr. f. Immun. forschg. 89, 18.

52) Frost, W. H., Frobisher, jr. M. van Volkenburgh, V. A. and Levin, M. L., (1936), Amer. jour of Hyg. XXIV: 568.

53) Whitley, O. R., (1936), Zbl. f. Bakt. I. Ref. 120, 451.

54) Preuss, H., (1936). Zbl. f. Bakt. I. Orig. 137, 105.

55) Erzin, N., (1936), Zbl. f. Bakt. I. Orig. 137, 97.

56) Hilgers, W. und Thoenes, F. (1936), Klin. Wschr. 15, 1567-1568.

57) Henneberg, G. und Pels Lenden, F., (1937), Zbl. f. Bakt. I. Orig. 139, 39.

58) Becher, W., (1937), Zbl. f. Bakt. I. Ref. 127, 389.

59) Otto, H. und Mittag, G., (1937), Klin. Wschr. 16, 294-296.

60) Wright, Joyce, (1937). Z Zb. f. Bakt. I, Ref. 127, 389.

61) Steigler, A., (1937), Zbl. f. Bakt. I. Orig. 138, 424.

62) Kemkes, B. und Steigler, A., (1937), Zeitschr. f. Hyg. und Infekt, CXIX; 296.

63) Hamburger, F., (1937), Die Diphtherie:Kurggefaßtes Handbuch. 12.

64) Zinsser \& Bayne-Jones. Textbook ot Bacteriology. 7th Edition. 465.

65) A system of Bacteriology. V; 67. (medical research council 1930).

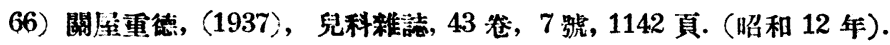

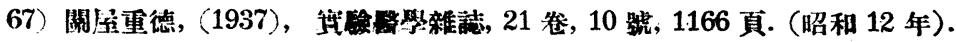

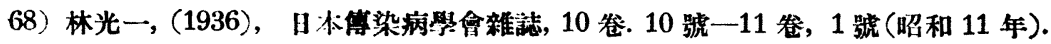

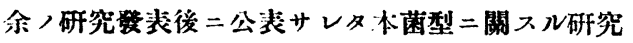

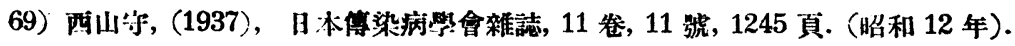

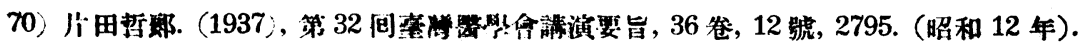

